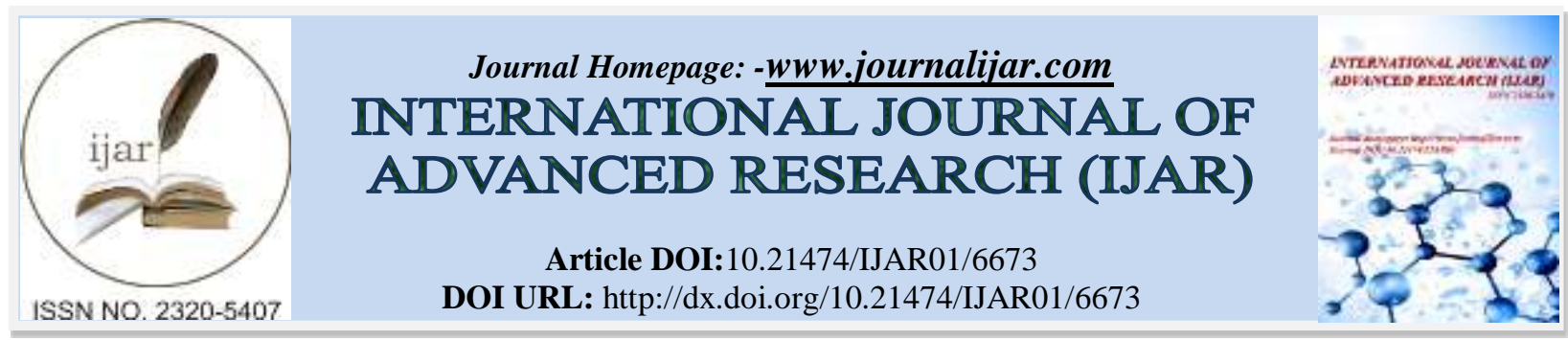

RESEARCH ARTICLE

\title{
A STUDY OF TEACHING COMPETENCY OF SECONDARY SCHOOL TEACHERS IN RELATION TO THEIR SOCIO-ECONOMIC STATUS.
}

\author{
Mohan Kumar $\mathbf{G}^{1}$ and Dr. M. Narayanaswamy ${ }^{2}$. \\ 1. Research Scholar, Department of Education, Bangalore University, Jnanabharathi, Bengaluru-560 056. \\ 2. Professor, Department of Education, Bangalore University, Jnanabharathi, Bengaluru-560 056.
}

\section{Manuscript Info}

Manuscript History

Received: 05 January 2018

Final Accepted: 07 February 2018

Published: March 2018

Keywords:-

Teaching Competency, Socio-Economic

Status, Secondary School Teachers, Sex,

Type of School Management.

\begin{abstract}
The present study was intended to investigate the relationship between Teaching Competency of secondary school teachers and their socioeconomic status. The study was conducted on a sample of 120 secondary school teachers selected by simple random sampling technique. Two tools were used to collect the data namely Teaching Competency Scale developed by the researcher and Socio-Economic Status Scale developed by the Kuppuswamy (1976) and revised by B.G. Prasad (2016). The data was analyzed by computing Pearson's Product Moment Coefficient of Correlation and independent ' $t$ ' test. The results revealed that there was a significant positive relationship between Teaching Competency of teachers and Socio-Economic Status. The results concludes that teachers having high level of SES had higher levels of teaching competency when compared with teachers having moderate and low levels of SES. The key implication of the study is to know the impact of socio-economic status on the performance of teachers. Policy makers may deal with to get better socio-economic conditions of secondary schools. The results inferred that teachers working in private unaided institutions had higher levels of teaching competency when compared with teachers working in private aided and government institutions. This implies that government and aided school managements should conduct in-service training programmes, orientation programmes and workshops which should focus on a need for higher levels of Teaching Competency. The results also found that there was no significant difference in Teaching Competency of secondary school male and female teachers.
\end{abstract}

Copy Right, IJAR, 2018,. All rights reserved.

\section{Introduction:-}

Teachers are vital piece of any general public for various reasons and their obligation in the public arena is similarly enormous and gainful. A definitive procedure of education could be rearranged as a significant communication between the educator and the teaching. The student-teacher connection is in the fore front and other significant benefactors are out of sight. This reality underscores the part of the teacher in learning and teaching process. The teacher in this manner plays a direct and a pivotal part in orderly students towards education. Late research has recognized teacher quality as the most essential variable in expanding student accomplishment.

Corresponding Author:- Mohan Kumar G. Address:- Research Scholar, Department of Education, Bangalore University, Jnanabharathi, Bengaluru560056. 
Competency implies the nature of conduct which reflects having essential or sufficient capacities or characteristics to fulfill the requests of a specific duty and the normal for viable execution which incorporates the capacity, learning, and ability to perform at a coveted level. A standout amongst the most capable components identified with execution of school is Socio Economic Status (SES) and it is the combination of income, occupation and education level that portrays a family or person. It reliably predicts teachers' execution and in addition job satisfaction as an integrative piece of school performance ought to be likewise influenced. Teachers in high economic status are not just ready to give their family's essential needs yet in addition ready to give a more uncommon time to learning, planning materials and media required in tomorrow's teaching-learning process. Despite what might be expected, teachers in low economic status are not just ready to give their family's fundamental needs yet in addition are not ready to give time and offices at home to build up their insight and aptitudes expected to manage the present difficulties.

The issue of teaching competency has occupied educational research for several decades and highlights the importance of teaching competency and socio economic status of teachers. Das and Nalinilatha (2017) recognized teaching competencies of secondary school teachers and the outcomes uncovered that no huge contrasts towards teaching competency among chose secondary school teachers concerning gender and type of management. Pratibha (2017) introduced an investigation of teaching competency of grade school teachers in connection to their sex and reasoned that sex did not influence the general teaching competency of elementary school teachers. Rajammal (2015) directed an investigation on the teaching competency of school teachers and induced that teachers fundamentally vary in Teaching Competency in regard of sex, types of school and socio-economic status of teachers. Chingtham (2014) analyzed the investigation of socio economic status and job satisfaction of private based school teachers in Manipur and stated that the demands on teachers of low socio-economic status, professional troubles, insufficient service condition and higher responsibilities and less salary and the issues found by the examination. Werang (2012) led an investigation of teachers' socio-economic status and its association with teachers' job performance at state senior high schools in Merauke Regency of Indonesia and discovered noteworthy connection between teachers' SES and teachers' job performance.

From the above studies it is clear that teacher's socio economic status is most important for teacher and as well as teaching competency. SES of teacher is lower than other professions like doctors, engineers, advocates and other professions. Hence, this study will focus on the socio-economic status influencing the teachers' competency in teaching particularly in Bengaluru Metro City.

\section{Significance of the Study:-}

Unquestionably, teachers hold a key to an effective and prosperous country. With no uncertainty, today less number of individuals picks teaching as a profession. Tragically, the reasons are absence of salaries, development prospects and over workload. Without a doubt, today teachers experience the ailing effects of long working hours and absence of pay for their work. Delineating this, one can see that with developing swelling it is getting to be expanding troublesome for teachers to get by in low salaries. What's more, long working hours preclude the teachers to take a moment job as another method for money and furthermore it has turned out to be difficult to show understudies viably. There is no denying the way that teaching is an exceptionally important and respectable profession in a general public. In this manner, everybody should work together to regard a teaching job to a highest level. Without a doubt, a general public can accomplish this by dealing with their current teachers, expanding their offices like salaries, impetuses, promotions and reduction their job workload for better teaching competency. The impact of the teachers on understudy accomplishment has been appeared to be more noteworthy than impacts because of his teaching competency and socio-economic status. Since an educator is a good example for the understudies, teaching competency of an instructor turns out to be exceptionally in the field of education. In this way the analyst wanted to explore the Teaching Competency relate with socio-economic status of secondary school teachers.

\section{Statement of the Problem:-}

"A Study of Teaching Competency of Secondary School Teachers in relation to their Socio-Economic Status" 


\section{Objectives of the Study:-}

1. To find out the relationship between Teaching Competency of secondary school teachers and their socioeconomic status.

2. To find out whether differences in the socio-economic status of secondary school teachers would account for significant differences in their Teaching Competency.

3. To find out whether differences in the background variables (sex, type of school management) and independent variable (socio-economic status) would account for significant differences in the Teaching Competency of secondary school teachers.

\section{Hypotheses of the Study:-}

The following null hypotheses have been formulated for empirical validation.

1. There is no significant relationship between Teaching Competency and Socio-Economic Status of secondary school teachers.

2. There is no significant difference in the Teaching Competency of secondary school teachers having different levels of socio-economic status (low, moderate and high).

3. There is no significant difference in the Teaching Competency of male and female secondary school teachers.

4. There is no significant difference in the Teaching Competency of secondary school teachers working in varied types of school management (government, private aided and private unaided institutions).

\section{Methodology:-}

Research Design:-

The present research is a descriptive survey method

Operational Definitions:-

The following terms have been used in the study.

\section{Teaching Competency:-}

For the present study teaching competency means the right way of assigning units of knowledge, application and skills to the students. It has six dimensions such as classroom management, content knowledge, using instruction methods, student motivation, presentation \& communication skills and measurement \& evaluation.

\section{Socio-Economic Status (SES):-}

It is defined as an individual's or group's position within a hierarchical social structure (income, occupation, and level of education). Socio-economic status measurement is the scores on Socio-Economic Status by revised Kuppuswamy and B.G. Prasad (2016).

\section{Secondary school teachers:-}

The secondary school teachers are the teachers who teach class IX to X.

Variables of the Study:-

The following variables were treated for the study:

\begin{tabular}{|l|l|}
\hline I. Dependent variable & II. Independent variable \\
\hline Teaching Competency & Socio-Economic Status \\
\hline & III. Background Variables : Sex and Type of Mgmt. \\
\hline
\end{tabular}

Sample of the Study:-

A simple random sampling technique was used to select the sample. The sample comprised 120 secondary school teachers of Bengaluru Metro City (South division). The sample included 11 male and 109 female teachers.

\section{Tools of Research:-}

The following tools were used to collect data

\section{Teaching Competency Scale (TCS):-}

The TCS developed by the researcher (2016) was used in the present study to measure teaching competency of secondary school teachers. The scale consists of 55 items distributed over the six dimensions such as classroom 
management, content knowledge, using instruction methods, student motivation, presentation \& communication skills and measurement \& evaluation. The test -retest reliability of the scale was 0.72 .

\section{Socio-Economic Status (SES):-}

The SES developed by the Kuppuswamy (1976) and revised by B.G. Prasad (2016) was used to assess the socioeconomic status of secondary school teachers.

\section{Statistical Techniques used to Analyze the Data:-}

The Pearson's Product Moment Coefficient of Correlation was computed to find out the relationship between the dependent (teaching competency) and independent variable (socio-economic status) and ' $t$ ' test was used to find out whether differences in the background and independent variables namely sex, type of school management and socioeconomic status levels would account for significant differences in the dependent variable (Teaching Competency) of secondary school teachers.

\section{Analysis and Interpretation of Data:-}

The data was analyzed by computing coefficient of correlation in the following table along with graphical presentation.

\section{Table-1:-}

Table shows Karl Pearson's Product Moment Coefficient of Correlation and its significance between Teaching Competency and Socio-Economic Status of secondary school teachers ( $\mathrm{N}=120$ and $\mathrm{df}=118)$.

\begin{tabular}{|c|c|c|c|c|}
\hline Variables & $\begin{array}{c}\text { Obtained } \\
\text { 'r' value }\end{array}$ & $\begin{array}{c}\text { Sig. } \\
\text { (P Value) }\end{array}$ & Table Value & Level of Sig. \\
\hline Teaching Competency and Socio-Economic Status & 0.308 & 0.001 & $\begin{array}{c}0.174(0.05) \\
0.228(0.01)\end{array}$ & $\begin{array}{c}\text { Significant at } \\
0.01 \mathrm{level}\end{array}$ \\
\hline
\end{tabular}

The above table-1 shows that the obtained ' $r$ ' value 0.308 is greater than the table value 0.228 at 0.01 level of confidence, therefore the stated null hypothesis is rejected and an alternate hypothesis has been formulated that "there is a significant positive relationship between Teaching Competency and Socio-Economic Status of secondary school teachers." The correlation between Teaching Competency and Socio-Economic Status of secondary school teachers is graphically presented with scatter diagram with $\mathrm{R}^{2}$ in Fig. 1 .

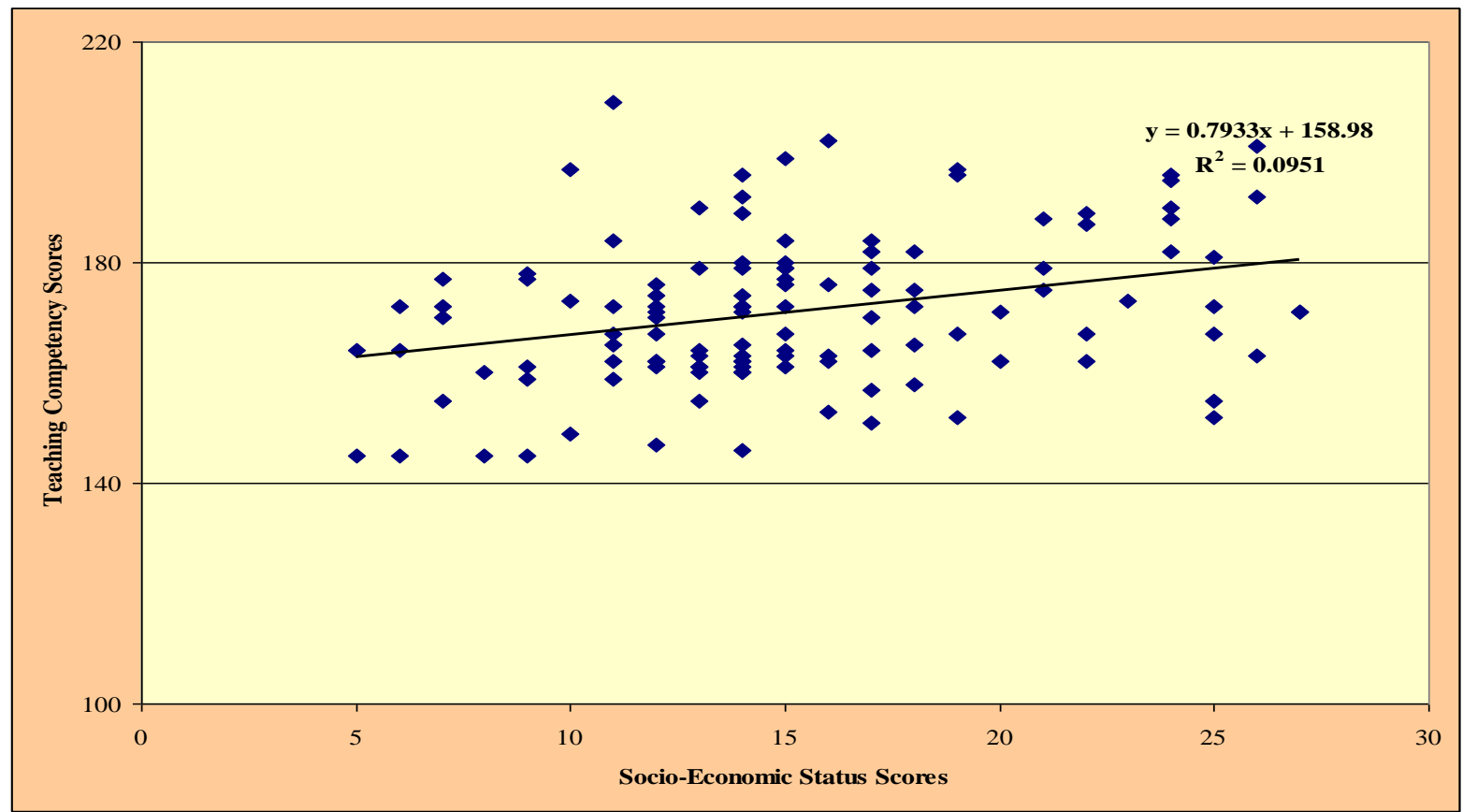

Fig.1:- Scatter diagram shows correlation of Teaching Competency and Socio-Economic Status of secondary school teachers. 
Table-2:- Table shows the Number, Mean, Standard Deviation, ' $t$ ' value and its level of significance of the Teaching Competency scores of secondary school teachers due to variations in the socio-economic status (SES), sex and type of school management.

\begin{tabular}{|c|c|c|c|c|c|c|c|c|}
\hline \multicolumn{2}{|c|}{ Variable and Groups } & \multirow{2}{*}{$\mathbf{N}$} & \multirow{2}{*}{$\begin{array}{c}\text { Mean } \\
158.000\end{array}$} & \multirow{2}{*}{$\begin{array}{c}\begin{array}{c}\text { Standard } \\
\text { Deviation }\end{array} \\
12.308\end{array}$} & \multirow{2}{*}{$\begin{array}{c}\text { Obtained } \\
\text { 't' value }\end{array}$} & \multirow{2}{*}{$\begin{array}{c}\text { Sig. } \\
0.081\end{array}$} & \multirow{3}{*}{$\begin{array}{c}\begin{array}{c}\text { Table } \\
\text { Value }\end{array} \\
1.98(0.05) \\
2.63(0.01)\end{array}$} & \multirow{2}{*}{$\begin{array}{c}\text { Sig. Level } \\
\text { Sig. at }\end{array}$} \\
\hline \multirow{6}{*}{$\begin{array}{l}\text { Socio- } \\
\text { Economic } \\
\text { Status }\end{array}$} & Low & & & & & & & \\
\hline & Moderate & 99 & 170.686 & 13.168 & & & & 0.05 level \\
\hline & Moderate & 99 & 170.686 & 13.168 & \multirow{2}{*}{1.87} & \multirow[t]{2}{*}{0.000} & $1.98(0.05)$ & \multirow{2}{*}{$\begin{array}{c}\text { Not } \\
\text { Significant }\end{array}$} \\
\hline & High & 16 & 178.062 & 14.870 & & & $2.62(0.01)$ & \\
\hline & Low & 5 & 158.000 & 12.308 & \multirow[t]{2}{*}{3.02} & \multirow[t]{2}{*}{0.082} & $2.09(0.05)$ & \multirow{2}{*}{$\begin{array}{c}\text { Sig. at } \\
0.01 \text { level }\end{array}$} \\
\hline & High & 16 & 178.062 & 14.870 & & & $2.88(0.01)$ & \\
\hline \multirow[t]{2}{*}{ Sex } & Male & 11 & 167.545 & 13.299 & \multirow[t]{2}{*}{0.94} & \multirow[t]{2}{*}{0.367} & $1.98(0.05)$ & \multirow{2}{*}{$\begin{array}{c}\text { Not } \\
\text { Significant }\end{array}$} \\
\hline & Female & 109 & 171.504 & 13.824 & & & $2.62(0.01)$ & \\
\hline \multirow{6}{*}{$\begin{array}{c}\text { Type of } \\
\text { Management }\end{array}$} & Government & 40 & 163.525 & 11.538 & \multirow[t]{2}{*}{3.55} & \multirow[t]{2}{*}{0.001} & $1.99(0.05)$ & \multirow{2}{*}{$\begin{array}{c}\text { Sig. at } \\
0.01 \text { level }\end{array}$} \\
\hline & Private aided & 40 & 172.200 & 10.248 & & & $2.64(0.01)$ & \\
\hline & Private aided & 40 & 172.200 & 10.248 & \multirow[t]{2}{*}{1.88} & \multirow[t]{2}{*}{0.064} & $1.99(0.05)$ & \multirow{2}{*}{$\begin{array}{c}\text { Not } \\
\text { Significant }\end{array}$} \\
\hline & Private Unaided & 40 & 177.700 & 15.352 & & & $2.64(0.01)$ & \\
\hline & Government & 40 & 163.525 & 11.538 & \multirow[t]{2}{*}{4.67} & \multirow[t]{2}{*}{0.000} & $1.99(0.05)$ & \multirow{2}{*}{$\begin{array}{c}\text { Sig. at } \\
0.01 \text { level }\end{array}$} \\
\hline & Private Unaided & 40 & 177.700 & 15.352 & & & $2.64(0.01)$ & \\
\hline
\end{tabular}

From the above table-2, it can be inferred that the obtained ' $t$ ' value 2.24 is greater than the table value 1.98 at 0.05 level of significance. Hence, it was found significant at 0.05 level of confidence and the null hypothesis is rejected and alternate hypothesis has been accepted that "there is a significant difference in the Teaching Competency of secondary school teachers having low and moderate levels of SES." The results shows that teachers having moderate level of socio-economic status $(\mathrm{M}=170.686)$ had higher levels of teaching competency when compared with teachers having low level of SES (M=158.000).

The obtained ' $t$ ' value 1.87 is less than the table value 1.98 at 0.05 level of significance. Hence, the null hypothesis is accepted that "there is no significant difference in the Teaching Competency of secondary school teachers having moderate and high levels of SES.

The obtained ' $t$ ' value 3.02 is greater than the table value 2.88 at 0.01 level of significance. Hence, it was found significant at 0.01 level of confidence and the null hypothesis is rejected and alternate hypothesis has been accepted that "there is a significant difference in the Teaching Competency of secondary school teachers having low and high levels of SES. The results concludes that teachers having high level of SES (M=178.062) had higher levels of teaching competency when compared with teachers having low level of SES (M=158.000).

The obtained ' $t$ ' value 0.94 is less than the table value 1.98 at 0.05 level of significance. Hence, the null hypothesis is accepted that "there is no significant difference in the Teaching Competency of secondary school male and female teachers."

The obtained ' $t$ ' value 3.55 is greater than the table value 2.64 at 0.01 level of significance. Hence, it was found significant at 0.01 level of confidence and the null hypothesis is rejected and alternate hypothesis has been accepted that "there is a significant difference in the Teaching Competency of secondary school teachers working in Government and private aided institutions." The results summarizes that teachers working in private aided institutions (M=172.200) had higher levels of teaching competency when compared with teachers working in government institutions (M=163.525).

The obtained ' $t$ ' value 1.88 is less than the table value 1.99 at 0.05 level of significance. Hence, the null hypothesis is accepted that "there is no significant difference in the Teaching Competency of secondary school teachers working in private aided and private unaided institutions."

The obtained ' $t$ ' value 4.67 is greater than the table value 2.64 at 0.01 level of significance. Hence, it was found significant at 0.01 level of confidence and the null hypothesis is rejected and alternate hypothesis has been accepted that "there is a significant difference in the Teaching Competency of secondary school teachers working in Government and private unaided institutions." The results founds that teachers working in private unaided institutions (M=177.700) had higher levels of teaching competency when compared with teachers working in government institutions ( $M=163.525)$. 


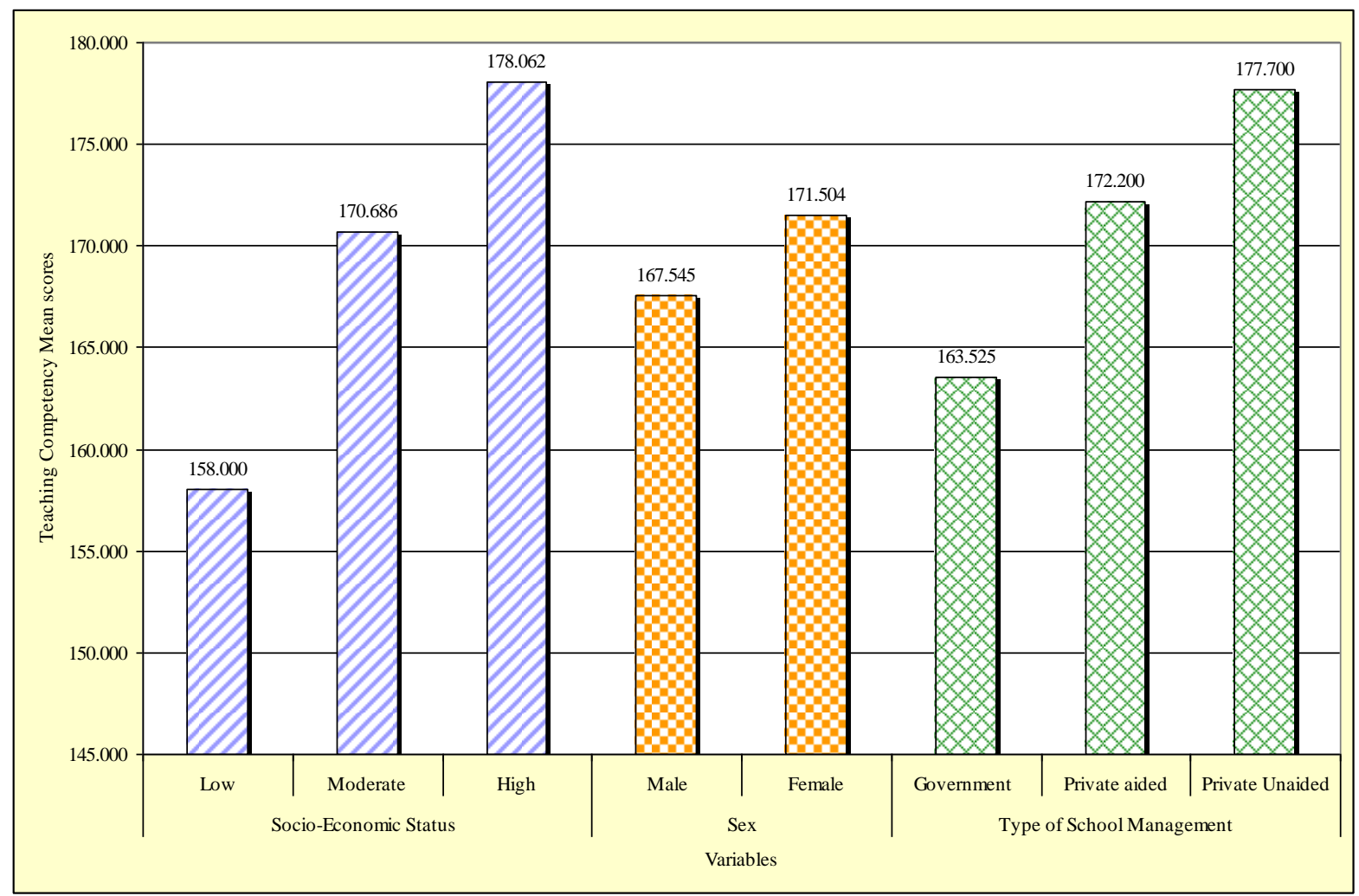

Fig.2:- Bar graph shows comparison of mean scores of Teaching Competency of secondary school teachers with regard to their socio-economic status, sex and type of school management.

\section{Major Findings:-}

The following are the major findings of the study

1. There exists significant positive relationship between Teaching Competency and Socio-Economic Status of secondary school teachers (' $\mathrm{r}$ ' $=0.308 ; \mathrm{P}<0.01$ ).

2. There exists significant difference in the Teaching Competency of secondary school teachers having low $(\mathrm{M}=158.000)$ and moderate $(170.686)$ levels of SES $(\mathrm{t}=2.24 ; \mathrm{P}<0.05)$.

3. There exists no significant difference in the Teaching Competency of secondary school teachers having moderate and high levels of SES $(\mathrm{t}=1.87 ; \mathrm{P}>0.05)$.

4. There exists significant difference in the Teaching Competency of secondary school teachers having low $(\mathrm{M}=158.000)$ and high $(\mathrm{M}=178.062)$ levels of SES $(\mathrm{t}=3.02 ; \mathrm{P}<0.01)$.

5. There exists no significant difference in the Teaching Competency of secondary school male and female teachers $(\mathrm{t}=0.94 ; \mathrm{P}>0.05)$.

6. There exists significant difference in the Teaching Competency of secondary school teachers working in government $(\mathrm{M}=163.525)$ and private aided $(\mathrm{M}=172.200)$ institutions $(\mathrm{t}=3.55 ; \mathrm{P}<0.01)$.

7. There exists no significant difference in the Teaching Competency of secondary school teachers working in private aided and private unaided institutions $(\mathrm{t}=1.88 ; \mathrm{P}>0.05)$.

8. There exists significant difference in the Teaching Competency of secondary school teachers working in government $(\mathrm{M}=163.525)$ and private unaided $(\mathrm{M}=177.700)$ institutions $(\mathrm{t}=4.67 ; \mathrm{P}<0.01)$.

\section{Conclusion:-}

From the statistical results, it was concluded that there is a significant positive relationship between Teaching Competency and Socio-Economic Status of secondary school teachers and also from ' $t$ ' test analysis it was found showed that there was significant difference in the Teaching Competency of teachers having different levels of SES. The results concludes that teachers having high level of SES had higher levels of teaching competency when compared with teachers having moderate and low levels of SES. The key implication of the study is to know the impact of socio-economic status on the performance of teachers. Policy makers may take care of to obtain better socio-economic conditions of secondary school teachers. Teaching profession may be completed good-looking 
through optimistic corroboration like awards, incentives, symbol of respect etc. The results also found that there was no significant difference in Teaching Competency of secondary school male and female teachers. There was significant difference in Teaching Competency of secondary school teachers working in government, private unaided and private unaided schools. The results inferred that teachers functioning in private unaided institutions had higher levels of teaching competency when compared with teachers functioning in private aided and government institutions. This entails that government and aided school authorities should carry out in-service training programmes, orientation programmes and workshops which should focal point on necessitate for elevated levels of teaching competency.

\section{References:-}

1. Best, J.W. (1978). Research in Education. New Delhi: Prentice Hall of India Pvt. Ltd.

2. Chingtham, Tomba (2014). Socio Economic Status and Job Satisfaction of Private School Teachers in Manipur. Voice of Research, 3(3), 8-9.

3. Das, Sijila M.K. and Nalinilatha, M. (2017). A Study on Teaching Competency of Secondary School Teachers. International Journal of Research Granthaalayah, 5(6), 508-513. Http://www.granthaalayah.com

4. Mangal, S.K. (2016). Essentials of Educational Psychology. $10^{\text {th }}$ Edition, Delhi: PHI Learning Private Limited.

5. Pratibha (2017). Teaching Competency of Primary School Teachers in Relation to their Sex and Educational Qualification. Abhinav National Monthly Refereed Journal of Research in Arts \& Education, 6(1), 13-20. www.abhinavjournal.com

6. Rajammal, T. Sivasakthi (2015). A Study on the Teaching Competency of School Teachers. International Contemporary Research Journal in Management and Social Science, 1(4), 41-46.

7. Werang, Basilius Redan (2012). Teachers' Socioeconomic Status and Its Relationship with Teachers Work Morale and Teachers' Job Performance at State Senior High Schools in Merauke Regency-Indonesia. International Journal of Science and Research, 3(8), 436-440. www.ijsr.net 